\title{
FRITILLARIA MELEAGROIDES IN ROMANIA
}

\author{
OPREA Adrian ${ }^{1}$, SÎRBU Culițăă ${ }^{2 *}$ PEREGRYM Mykyta ${ }^{3}$
}

\begin{abstract}
The presence in the spontaneous flora of Romania of the species Fritillaria meleagroides is reported in this paper. It was identified in the North of the village Cotu Morii (Popricani Commune, Iaşi County), on (meso-) hygrophilous, slightly halophilous meadows, placed on the both sides of an old meander of the Jijia river. This place is at the western limit of natural area of $F$. meleagroides, which stretches from the Central Asia to the Eastern Europe (European Russia, Ukraine and Bulgaria). Since F. meleagroides is an endangered species in large part of its natural range, we consider that urgent actions to protect its populations from Romania are necessary.

Keywords: botanical description, identification key, marginal populations, new records, vascular flora
\end{abstract}

Received 26 November 2015

Accepted 05 December 2015

\section{Introduction}

The vascular flora of Romania has been studied of approx. two centuries by numerous botanists. However, the research of the flora still can give us nice surprises and new recordings of species, both indigenous and adventive, have been done in the last decades, increasing the inventory of the vascular flora of Romania (Oprea 2005, Ciocârlan 2009, Sârbu et al. 2013).

One of the genera from the vascular flora of Romania is Fritillaria L. (Liliaceae) (Zahariadi 1966, Ciocârlan 2009, Sârbu et al. 2013). This genus comprises between 100 and 160 species (depending on the points of view of different authors), occurring in most temperate regions of the Northern Hemisphere (Zahariadi 1966, Rønsted et al. 2005, Tomović et al. 2007, Türktaş et al. 2012, Karakaş Metin et al. 2013).

In the most recent classification, which is supported by the molecular phylogenetic data, eight subgenera of Fritillaria have been separated (Rønsted et al. 2005). Among these, the subgenus Fritillaria (with subglobose bulbs, usually consisting of two fleshy scales, more or less tunicated by the translucent remains of the previous years scales) is the largest one, widely distributed from the Western Europe and the Mediterranean region to Eastern Asia (Rønsted et al. 2005, Peruzzi et al. 2008). According to Rønsted et al. (2005), species of this subgenus with a trifid style are

\footnotetext{
${ }^{1}$ Botanical Garden "Anastasie Fătu", University "Alexandru Ioan Cuza", 700487-Iaşi, Romania

2 Faculty of Agriculture, University of Agricultural Sciences and Veterinary Medicine "Ion Ionescu de la Brad", 700487-Iaşi, Romania, e-mail: culita69@yahoo.com

3 Botanical Garden "O.V. Fomin", Educational and Scientific Centre "Institute of Biology", "Taras Shevchenko" National University of Kyiv, Ukraine
} 
included in the section Fritillaria, while species with an undivided style are included in the section Olostylea Boiss.

Two species of the genus, both of them belonging to the section Fritillaria, have been known in the spontaneous flora of Romania, till now, namely (Zahariadi 1966, Sârbu et al. 2013): F. meleagris L. and F. montana Hoppe ex. W. D. J. Koch (syn.: F. degeniana J. Wagner; $F$. orientalis auct., non Adam; F. tenella auct., non M. Bieb.).

Fritillaria meleagris occurs in the wild both in Europe (from the Great Britain and Central Russia south to the Southern Alps and Western Balkans) (LozinaLozinskaya 1935, Zahariadi 1966, Rix 1980, Sârbu et al. 2013) and Asia (Western Siberia and Altai) (Vlasova 1987). It has been mentioned in Romania since the first decades of the 19th century (Baumgarten 1816). It is a (meso)-hygrophilous species (Sârbu et al. 2013) spread sporadically, from the steppe zone, up to the spruce forest belt, through meadows, thickets, coppices or open deciduous forests (Zahariadi 1966, Csergö \& Frink 2003, Oprea 2005; Sârbu et al. 2013), in the structure of plant communities from various alliances, such as: Potentillion anserinae R. Tx. 1947 (Ularu \& Parascan 1970, Sămărghițan \& Oroian 2011, Sârbu et al. 2013), Molinion W. Koch 1926, Calthion Tx. 1937, Magnocaricion W Koch 1926 (Csergő \& Frink 2003), Alnion incanae Pawłowski, Sokołowski et Wallisch 1928 (Bujorean \& Grigore 1965, Maloş et al. 1967, Ularu \& Parascan 1970), or Salicion cinereae Müller et Görs ex Passarge 1961 (Bujorean \& Grigore 1965, Ularu \& Parascan 1970).

Its populations have been greatly affected by the massive collecting during flowering time, as well as by the anthropogenic disturbance of habitats (Pop \& Sălăgeanu 1965, Csergő \& Frink 2003). Therefore, in order to protect its populations, the species was declared a "monument of nature" in Romania, being protected by law (Pop \& Sălăgeanu 1965, Zahariadi 1966).

Fritillaria montana is native in the South-Eastern Europe (Zahariadi 1966, Peruzzi et al. 2008, Mancuso et al. 2012) or in the Pontic-Mediterranean area (Sârbu et al. 2013). It has been reported in Romania (under various names) since the first half of the 19th century (1844) (Simonkai 1886). Like in other European countries (see comments in Peruzzi et al. 2008, Peruzzi \& Bartolucci 2009), this species has a complicated taxonomic history in Romania. Authors from the 19th century (Heuffel 1858, Fuss 1866, Schur 1866, Kanitz 1879-1881, Brândză 1879-1883, Simonkai 1886, Grecescu 1898) mentioned it using the misapplied name of $F$. tenella M. Bieb., for which they gave several synonyms (including $F$. montana). Prodan (1939) noticed for the first time that the plant from Romania is not $F$. tenella M. Bieb., reporting it as " $F$. degeniana J. Wagner $(F$. tenella auct.)". The name of $F$. montana was for the first time used correctly in the Romanian literature by Zahariadi (1966). This author also demonstrated, by analyzing herbarium specimens, that $F$. montana Hoppe and $F$. orientalis Adam (syn. F. tenella M. Bieb.) are two distinct species, as they actually were also treated in the Flora of USSR (Lozina-Lozinskaya 1935), and that the latter (an East Pontic species from the Caucasus Mountains) do not grow in Romania. Subsequently, however, with some exceptions (Sârbu et al. 2013), the species continued to be erroneously reported in Romania, either as F. tenella Bieb. (Beldie 1979) or as $F$. orientalis Adams (Ciocârlan 2009), probably (in the second case) under the influence of the erroneous taxonomic treatment of the Flora Europaea (Rix 1980).

Fritillaria montana is a mesophilous species spread sporadically in Romania, through shrubs and deciduous forests, from the forest steppe zone, up to the beech forest 
belt (Zahariadi 1966, Sârbu et al. 2013). It grows in plant communities of the orders Quercetalia pubescentis Br.-B1. (1931) 1932 and Orno-Cotinetalia Jakucs 1961 (Chifu et al. 2006, Sârbu et al. 2013), or of the alliances Alnion incanae Pawłowski, Sokołowski et Wallisch 1928 and Lathyro hallersteinii-Carpinion Boşcaiu 1979 (Chifu et al. 2006).

Although both $F$. meleagris and $F$. montana are included in some national red lists, as vulnerable or rare (e.g. Oltean et al. 1994, Sârbu \& Chifu 2001) and the latter is included in the European list of threatened species which are present in Romania (Sârbu et al. 2003), however, none of them are listed in The Red Book of vascular plants of Romania (Dihoru \& Negrean 2009).

In the spring of 2015, we identified another spontaneous species of Fritillaria unknown in Romania till now, which is reported in this paper.

\section{Material and methods}

The species was recorded during our recent field work (2015), in the North East Romania. Specimens collected on the field were deposited in the herbarium of the University of Agricultural Sciences and Veterinary Medicine Iaşi (IASI), as well as in the herbarium of the Botanic Garden "Anastasie Fătu", University "Alexandru Ioan Cuza" of Iaşi (IAGB). The geographic coordinates were recorded using an eTrex Legend HCx GPS system. The species was identified using several standard floras (Lozina-Lozinskaya 1935, Yanev 1964, Rix 1980, Chen \& Mordak 2000), but it was also checked in other references (Ledebour 1830a, b, 1853, Pachoskiy 1914, Artiushenko 1979, Prokudin et al. 1987, Hill 2008, 2010) and compared to its original diagnosis (Schultes \& Schulthes 1829). Morphological characters of 10 specimens were analyzed both on the field and in the above mentioned herbaria. Seed sections were prepared and analysed using an Optica B-350 microscope, in order to examine the membranous edge of the seed. Biological and ecological features of the species were noted in the field and compared with data from references. The nomenclature of the cited plant taxa follows Sârbu et al. (2013), except the species for the first time reported in the flora of Romania (Rix 1980).

\section{Results and discussion}

Fritillaria meleagroides Patrin ex Schult. \& Schult. fil., unknown in the flora of Romania until now, has been identified (on April, 23 ${ }^{\text {rd }}, 2015$ ), in the North-Eastern Romania, to the North of the village Cotu Morii (Popricani commune, Iaşi county), and to the East of the fish farm "Acvares", on both sides of an old meander of the Jijia river (Fig. 1 and 2). This meander, forming two unequal sinuosities (a smaller one toward the Jijia river, and a larger one, on the opposite side), is located between a dike delimiting eastward the ponds of the "Acvares" farm and the collector channel, \pm parallel to the dike. On that area, we have identified three populations of $F$. meleagroides. A smaller one of approx. 50 specimens has been located on the meadow between the smaller sinuosity of the meander and the collector channel (N47 $\left.19^{\prime} 0.05^{\prime \prime}, \mathrm{E} 27^{\circ} 33^{\prime} 4.88^{\prime \prime}\right)$. Other two populations of several hundred specimens each, have been located northward, on the one side $\left(\mathrm{N} 47^{\circ} 19^{\prime} 23.59^{\prime \prime}\right.$, E2 $\left.7^{\circ} 33^{\prime} 6.23^{\prime \prime}\right)$, respectively on the other side $\left(\mathrm{N} 47^{\circ} 19^{\prime} 35.58^{\prime \prime}, \mathrm{E} 27^{\circ} 33^{\prime} 9.01^{\prime \prime}\right)$ of the terminal sinuosity of the meander. 


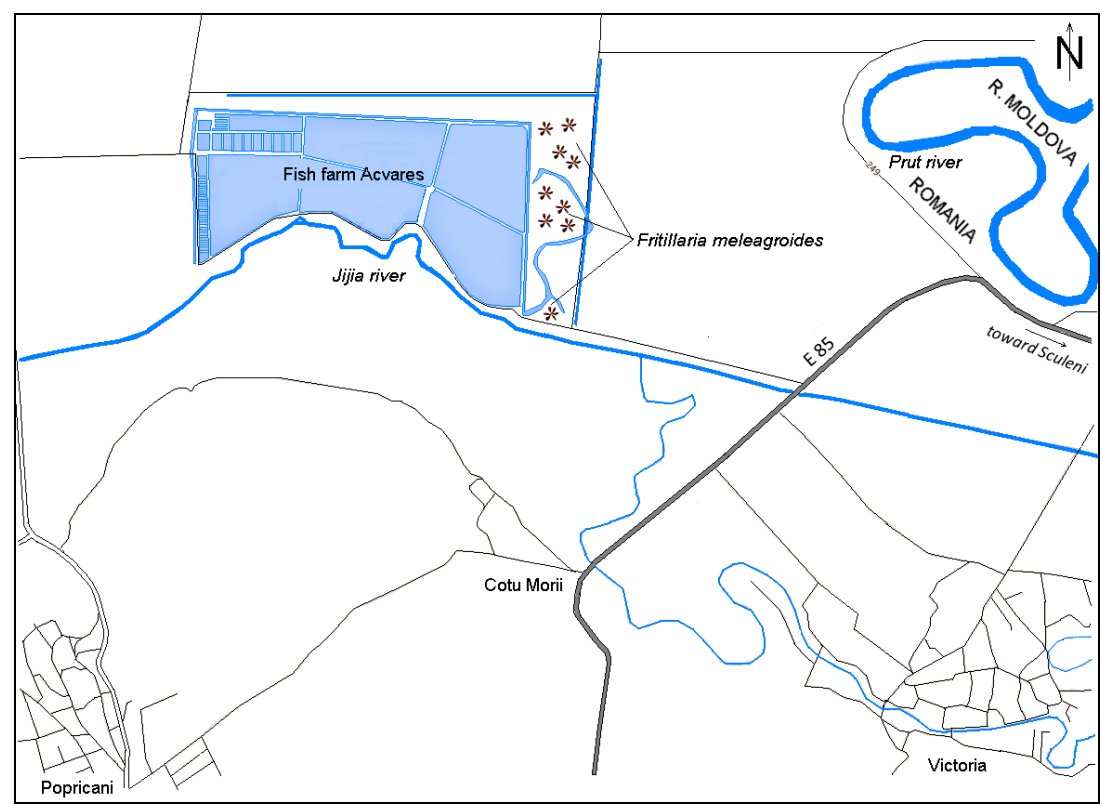

Fig. 1. Map indicating the location of F. meleagroides in the NE Romania

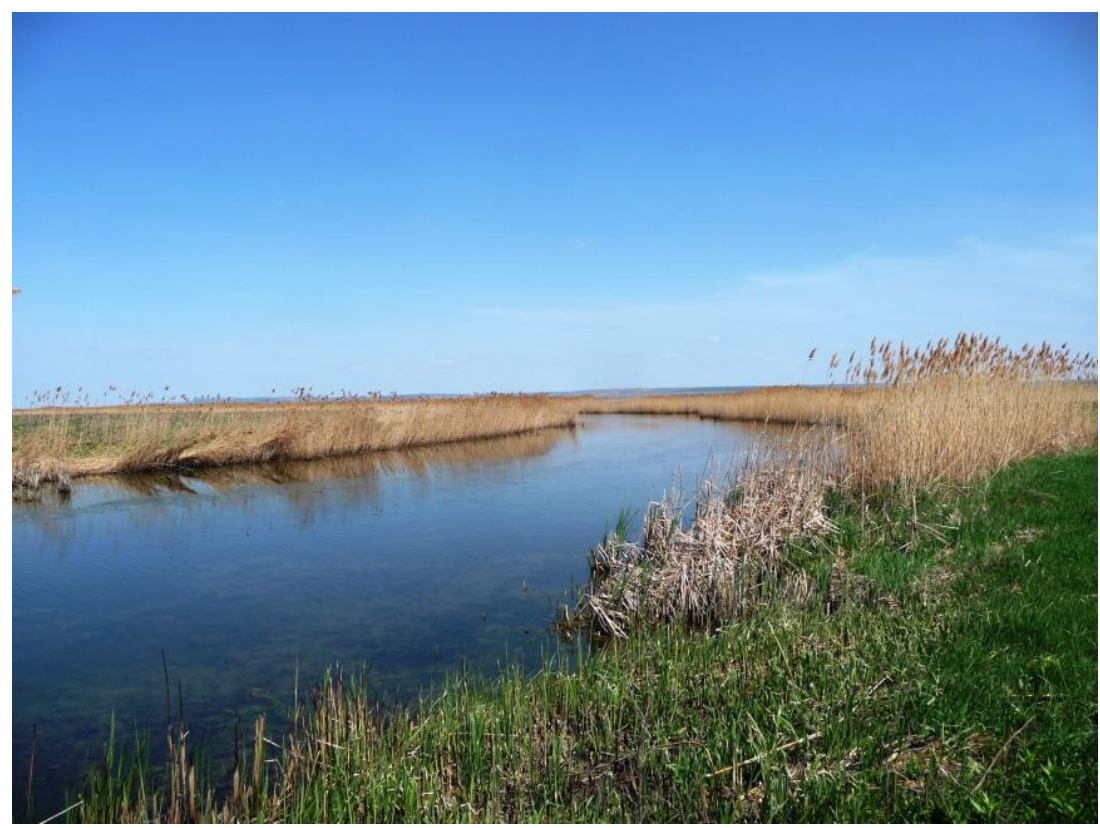

Fig. 2. The old meander of Jijia river, within the studied area 


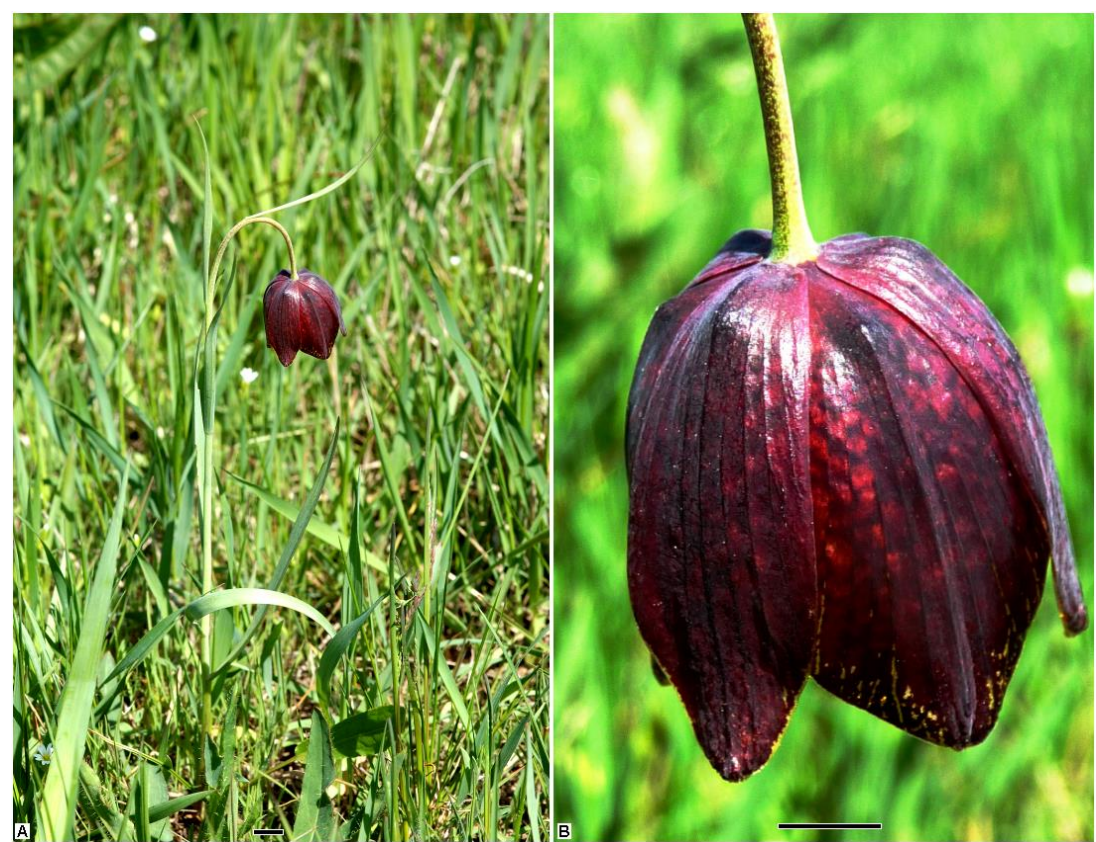

Fig. 3. Fritillaria meleagroides from NE Romania: A-general habitus; B-the flower. Scale bar: $1 \mathrm{~cm}(\mathrm{~A}), 0.5 \mathrm{~cm}(\mathrm{~B})$
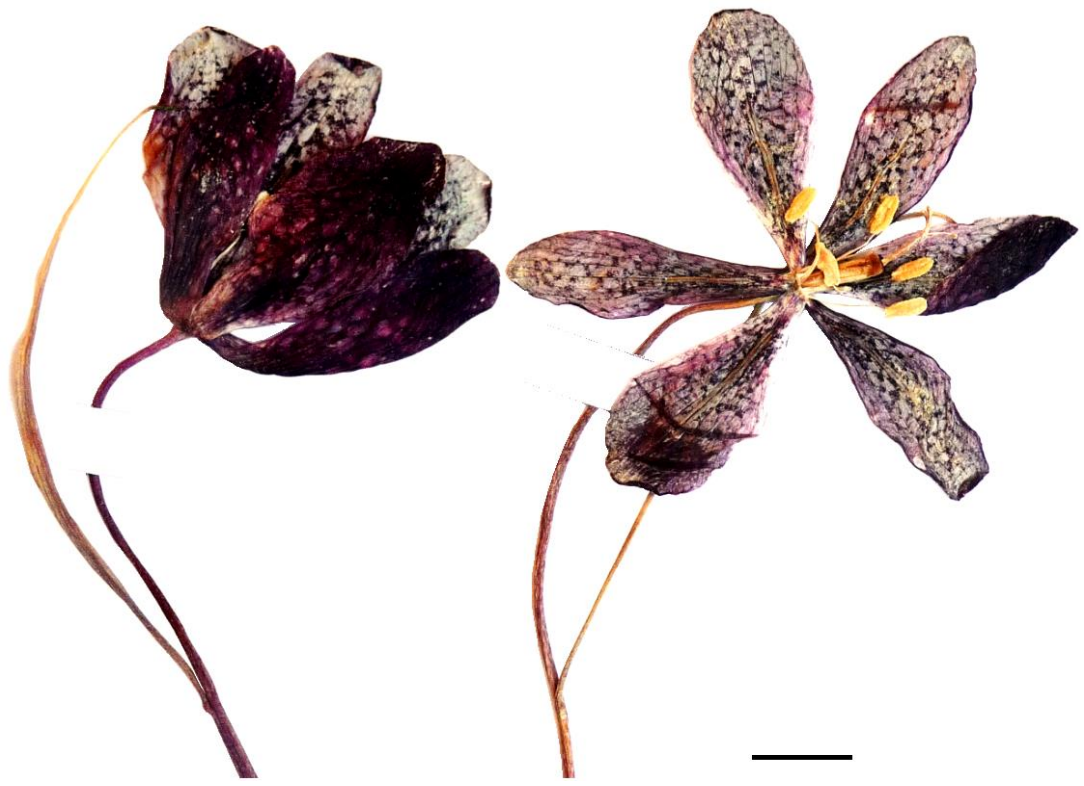

Fig. 4. Flowers of F. meleagroides from herbarium specimens. Scale bar: $1 \mathrm{~cm}$ 
Botanical description. The following description of the species is based on the specimens examined on the field and herbarium specimens (IASI 17977; IAGB 47674, 47675; leg. A. Oprea, C. Sîrbu; det. M. Peregrym, C. Sîrbu, A. Oprea) collected from the above mentioned locality.

Perennial. Bulb \pm globose, $10-12 \mathrm{~mm}$ in diameter, with a whitish-brown, translucent tunic. Stems $28-50 \mathrm{~cm}$ long, glabrous, smooth, green-glaucous, sometimes purple spotted, internodes very unequal. Leaves 5-7, alternate, sessile, linear, attenuate toward apex, glabrous, the lowermost 11-14 $\times 5-8 \mathrm{~mm}$, the above gradually smaller.

Flower (Figs 3, 4) solitary, campanulate, nodding; peduncle $2.9-9 \mathrm{~cm}$ long. The ratio between the length of the peduncle and the bracteant (upper) leaf is variable, between 0.5 and 2. Tepals 25-28 mm long, sub equal, blackish-purple outside, greenish inside, obscurely (faintly) tessellated, the outer ones oblong-elliptic, 8-11 mm wide, the inner ones obovate, wider $(12-18 \mathrm{~mm})$. Nectaries (on the adaxial surface of tepals) greenish yellow, linear, of 12-18 $\times 1-1.5 \mathrm{~mm}$, placed at $4-5 \mathrm{~mm}$ above the base of the tepals. The outer gibbosity of tepals, corresponding with the inner nectariferous fovea, weak developed. Stamens slightly longer than $1 / 2$ of tepals; filaments papillose, 7-11 $\mathrm{mm}$ long, slightly widened towards the base; anthers yellow, basifixed, 4-9 $\times 1.5-2 \mathrm{~mm}$ (the open anthers are shorter than the ones unopened yet !). Ovary 3-sided, 7-9 mm long; style 5-7 mm long, papillose, 3-branched, the branches 3-4 $\mathrm{mm}$ long, papillose. Capsule (Fig. 5) erect at ripening, obtusely 3-angled, wingless, 15-35 × 8-12 mm, strongly narrowed at the bottom (on a length of 1-4 mm). Seeds (Fig. 6) numerous, in two rows per locule, yellowish brown, triangular-ovate, $4-6 \times 3-4 \mathrm{~mm}$, flattened $(0.3-$ $0.4 \mathrm{~mm}$ thickness, in the central region), with a membranous swollen edge, filled with air, as a tire.

General distribution. The natural range of $F$. meleagroides stretches from Northwest China (Xinjiang), through Central Asia (Altai, Kazakhstan, Western Siberia), Northwest Caucasus, to Eastern Europe (Lozina-Lozinskaya 1935, Yanev 1964, Chen \& Mordak 2000, Korotchenko \& Orlov 2009). In the neighbourhood of Romania, $F$. meleagroides has been reported in the central, eastern and southern regions of Ukraine (Lozina-Lozinskaya 1935, Rix 1980, Prokudin et al. 1987, Korotchenko \& Orlov 2009), as well as in western Bulgaria (Yanev 1964, Rix 1980, Andreev 1993, Assyov \& Petrova 2006, Petrova \& Vladimirov 2009, Ivanova 2015).

The presence of this species in the Republic of Moldova (Geideman 1986, Negru 2002, 2007, Ciubotaru et al. 2007), although very probable, has been recently invalidated by Pînzariu \& Sîrbu (2014). Both in the "Plant world of the Republic of Moldova", IV, p. 33 (Ciubotaru et al. 2007) and "The Red Book of the Republic of Moldova", p. 78 (Negru 2002), the description and iconography of the plant named $F$. meleagroides are rather suitable for $F$. montana (by upper leaves opposite or verticillate). In addition, the "Identification book of plants from the Republic of Moldova" (Negru 2007) contains the name "F. meleagroides" in the alphabetical index of taxa, but on the page indicated in the text, instead of $F$. meleagroides, another species ( $F$. meleagris) is mentioned. Therefore, without other reliable data, it seems reasonable that, according to Pînzariu \& Sîrbu (2014), F. meleagroides has been erroneously referred from this country, at least in some publications, by confusion with $F$. montana or with $F$. ruthenica.

Plant variability. Table 1 (columns 1-3) presents some data on the morphological variability of the species $F$. meleagroides resulted from the analysis of 
10 specimens from Romania. Data from botanical references were also presented in the table (columns 4-9), for comparison. According to our data, the next morphological characters of $F$. meleagroides populations from Romania had a more pronounced variability (i.e. $\mathrm{CV} \%>15 \%$ ): the plant height, the length of stem internodes, the width of lowermost leaf, the ratio between the length of the peduncle and the bracteant leaf, the length and width of capsule, the length of the narrowed basal region of the capsule.

The morphological variation of specimens analyzed from Romania generally fall within the limits described in the botanical references (Table 1), with the next interesting exceptions:

- tepals are wider as against data from references: 8-11 mm instead of 5-9 mm (outer tepals), respectively $12-18 \mathrm{~mm}$ instead of 7-12 $\mathrm{mm}$ (inner tepals);

- nectaries of variable length, between 12 and $18 \mathrm{~mm}$ (compared with $15 \mathrm{~mm}$, data from the literature) and narrower (1-1.5 $\mathrm{mm}$ ) than $2 \mathrm{~mm}$ (data from the literature);

- seeds are smaller (4-6 mm $\times 3-4)$, as against the literature data (6-6.6 $\times$ 4.8-5.2 mm).

Despite these differences, we are convinced that the plants identified by us belong to the species $F$. meleagroides. Populations from Romania are localized, as we shown, at the western border of the natural range of the species. Therefore, as in the case of many other species, a large morphological variability of the marginal populations, against of those from the inside of the distribution range, can be expected [see, for instance, Tomović et al. (2007), or for an extensive description of the topic, Crawford (2008)].

Taxonomic notes and identification key. Fritillaria meleagroides has been described in 1829 by Schultes \& Schultes fil., in Roemer \& Schultes, Systema Vegetabilium, 7: 395-396. Type of F. meleagroides (collector Patrin, 1791, in montibus Altai) is stored on the Muséum National d'Histoire Naturelle (Paris), P00730799 (GPD 2015).

It seems that the first reliable illustration of this species has been made by Ledebour (1830b), in the "Icones plantarum ... ", under the name of F. minor. In the Flora of USSR, Vol. 4, pp. 306, Lozina-Lozinskaya (1935) treated the name F. minor Ledeb. as a synonym for $F$. meleagroides, according to the principle of priority. However the diagnosis published by Ledebour (1830a) in "Flora Altaica" for his $F$. minor includes some characters which cannot be recognized at the plant illustrated by the same author in the "Icones plantarum ... " (Ledebour 1830b) and which are specific rather for $F$. ruthenica Wikst.: "Folia ..., apice plerumque incurvo ...; duo inferiora nonnunquam subopposita ...". For this reason, probably, in the Flora Europaea, Vol. 5 (Rix 1980), the name $F$. minor is accepted as a synonym not for $F$. meleagroides, but for $F$. ruthenica. However, by its upper leaves (bracts) verticillate and twisted (with a tendril-like apex) (Lozina-Lozinskaya 1935, Rix 1980), F. ruthenica obviously differs from the iconography of " $F$. minor" published by Ledebour (1830b), as well as from the "F. minor" specimens collected by the same author from Altai (see herbarium specimens digitized by the GPD 2015). In the meantime, reliable iconography of the species $F$. meleagroides has been enriched by the contributions of Yanev (1964), Hill (2008, 2010), Buko \& Maltseva (2012), Ivanova (2015) etc. We have to note, however, that some references give erroneously, for $F$. meleagroides, photos or drawings which actually represent other related species, such as: F. meleagris (Korotchenko \& Orlov 2009) or F. montana (Negru 2002, Ciubotaru et al. 2007). 


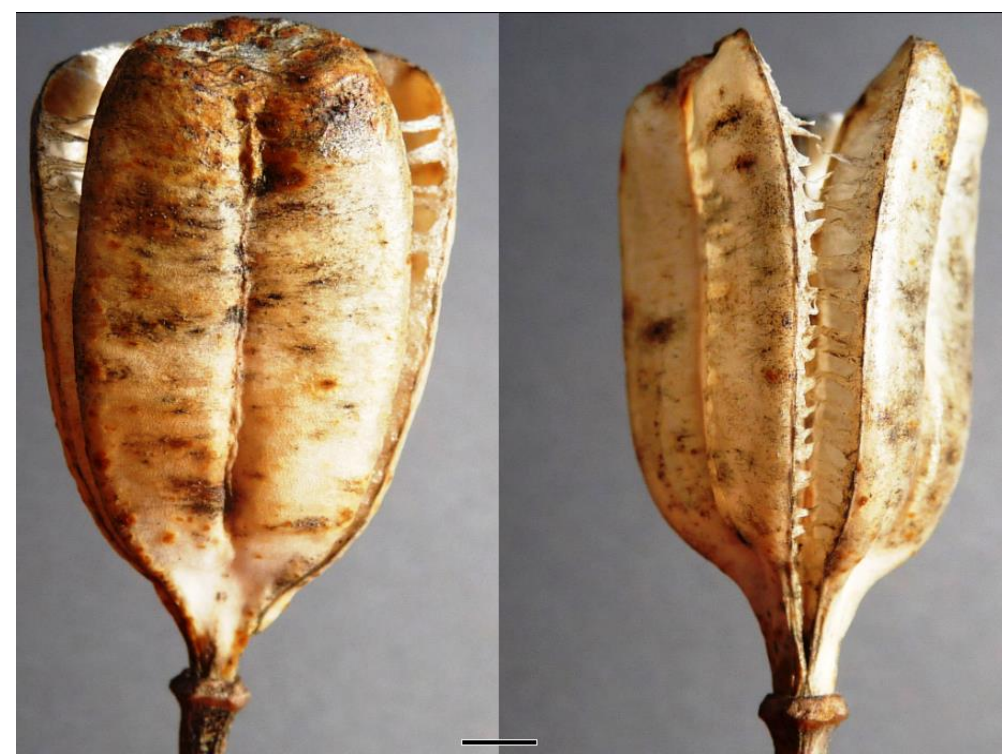

Fig. 5. Capsules of F. meleagroides. Scale bar: $2.5 \mathrm{~mm}$

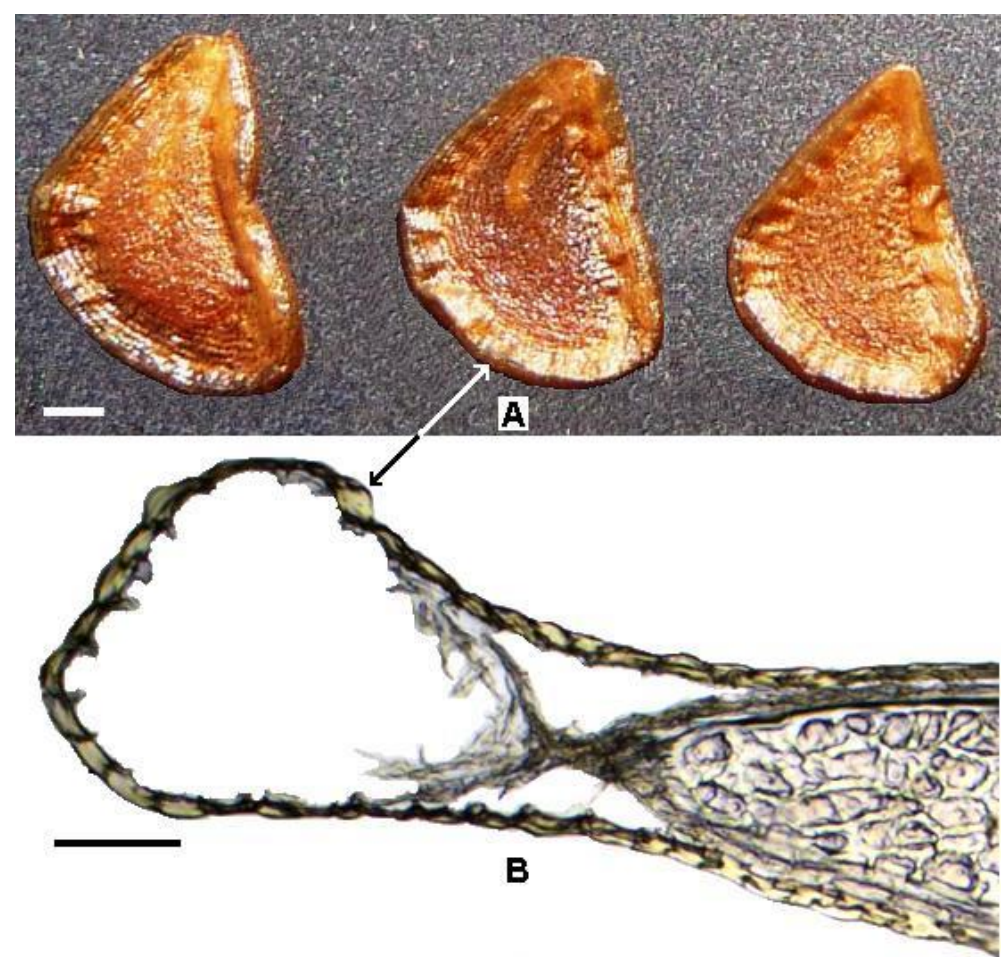

Fig. 6. Seeds of F. meleagroides (A-general view; B-cross-section). Arrows indicate the membranous swollen edge of the seed. Scale bar: $1 \mathrm{~mm}(\mathrm{~A}), 0.1 \mathrm{~mm}$ (B) 
In the identification key below, we show the main characters by which $F$. meleagroides can be easily distinguished from the other congeneric species previously known in the flora of Romania (Zahariadi 1966, Ciocârlan 2009, Sârbu et al. 2013), including the cultivated species $F$. imperialis:

1a Lowermost and middle leaves of 25-40 mm width. Flowers orange-red, (2) 3 to 6 (8) in a false umbel with erect bracts arranged in a tuft over the flowers. Tepals not tessellated. Nectaries more or less circular, white, at the base or slightly above the base of tepals. Plants cultivated in gardens F. imperialis

1b Leaves of 2-10 mm width. Flowers purple, blackish- or greenish-purple, pink or white, solitary or in racemes. Tepals more or less tessellated (marked with alternating squares of light and dark colour). Nectaries linear, starting at the point of inflection of tepals (4-12 $\mathrm{mm}$ above the base of the tepals). Plants spontaneous

2a Upper (and / or the lower) leaves opposite or verticillate (in a whorl of 3), the intermediate leaves alternate. Plants mesophilous F. montana

2b All leaves alternate. Plants \pm hygrophilous 3

3a Tepals of 30-45 (50) mm long, purple, pink or (rarely) white, obviously regular tessellated, the inner ones elliptical-elongate (wider at the middle). Nectaries at 8-12 $\mathrm{mm}$ above the base of tepals. The outer gibbosity of tepals, corresponding with the inner nectariferous fovea, very pronounced, \pm angular. Plants do not grow on salty soils F. meleagris

3b Tepals less than $30 \mathrm{~mm}$ long, blackish-purple outside, greenish inside, less obviously (obscurely) tessellated, the inner ones obovate (wider in the upper third). Nectaries at ca. $4 \mathrm{~mm}$ above the base of tepals. The outer gibbosity of tepals, corresponding with the inner nectariferous fovea, less obvious, rounded. Plants tolerate (slightly) salty soils

F. meleagroides

According to Rix (1980), nectaries are of $7-10 \times 1.5 \mathrm{~mm}$ at $F$. meleagris and 15 $\times 2 \mathrm{~mm}$ at $F$. meleagroides. This would be another important criterion for distinction between the two species. However, this criterion is not quite sure, since according to Stpiczyńska et al. (2012), at F. meleagris, nectaries are of $9.12-14.43 \mathrm{~mm}$ long (11 $\mathrm{mm}$, on average) and according to our data, at $F$. meleagroides, nectaries are rather variable in length and narrower $(12-18 \times 1-1.5 \mathrm{~mm})$.

Biology. According to Korotchenko \& Orlov (2009) and Ivanova (2015), F. meleagroides flourishes in April-May, is pollinated by insects and the fruits ripen in June. This is consistent with our observations on the field. In the northwestern China, it seems that the plant flourishes later on, in May-June (Chen \& Mordak 2000). It reproduces both by seeds and vegetative (bulbs), but the latter way is less effective (Korotchenko \& Orlov 2009, Ivanova 2015). We suppose that the swollen edge of the seed, filled with air (as a tire) is an adaptation for both anemochorous and hydrochorous seed dispersal. Although we have not done a detailed study on this issue, we noticed on the field that the seeds are easily carried by the wind. We have also found in the laboratory that the seeds float on the water for several days without sinking.

Ecology, habitats and plant communities. Throughout its natural area, $F$. meleagroides grows in wet habitats, temporary inundated (Golub \& Saveljeva 1991, Andreev 1993, Chen \& Mordak 2000, Korotchenko \& Orlov 2009, Didukh 2011, Ivanova 2015), often with an excess of salts (on solonetzs) (Lozina-Lozinskaya 1935, 
Artiushenko 1979, Prokudin et al. 1987, Golub \& Saveljeva 1991, Golub 1994). Plant communities in which the species usually grows, sometimes as a constant species, belong either to the halophilous wet meadows (e.g. the class Asteretea tripolium Westhoff et Beeftink in Beeftink 1962, partly synonymous with FestucoPuccinellietea Soó 1968) (Golub 1994) or to the wet meadows of the class MolinioArrhenatheretea R. Tx. 1937 em. Mirk. et Naumova 1986 (Golub \& Saveljeva 1991, Korotchenko \& Orlov 2009).

According to our preliminary data, the populations of $F$. meleagroides from Northeastern Romania grow under similar conditions, on wet meadows (Fig. 7), with temporary excess of moisture, which are mainly dominated by Agrostis stolonifera, Elymus repens and Alopecurus pratensis (alliance Potentillion anserinae), with an important presence of some halophilous species, characteristic for the class FestucoPuccinellietea Soó 1968 (e.g. Cerastium dubium, Dianthus pratensis subsp. racovitzae, Iris brandzae, Iris halophila, Juncus gerardi, Limonium gmelinii, Puccinellia distans subsp. limosa, Scorzonera cana, Rhaponticum serratuloides etc.). However, further research is needed for more detailed knowledge of the populations of $F$. meleagroides from Romania, concerning their structure, distribution, ecology, biology and phytosociology. Unfortunately, part of the territory occupied by this species in the northeastern Romania is currently anthropogenically disturbed, mainly by ploughing for agricultural crops. By its tolerance to soil salinity, $F$. meleagroides is clearly distinguishable from the two other congeneric species from the flora of Romania, $F$. meleagris and $F$. montana.

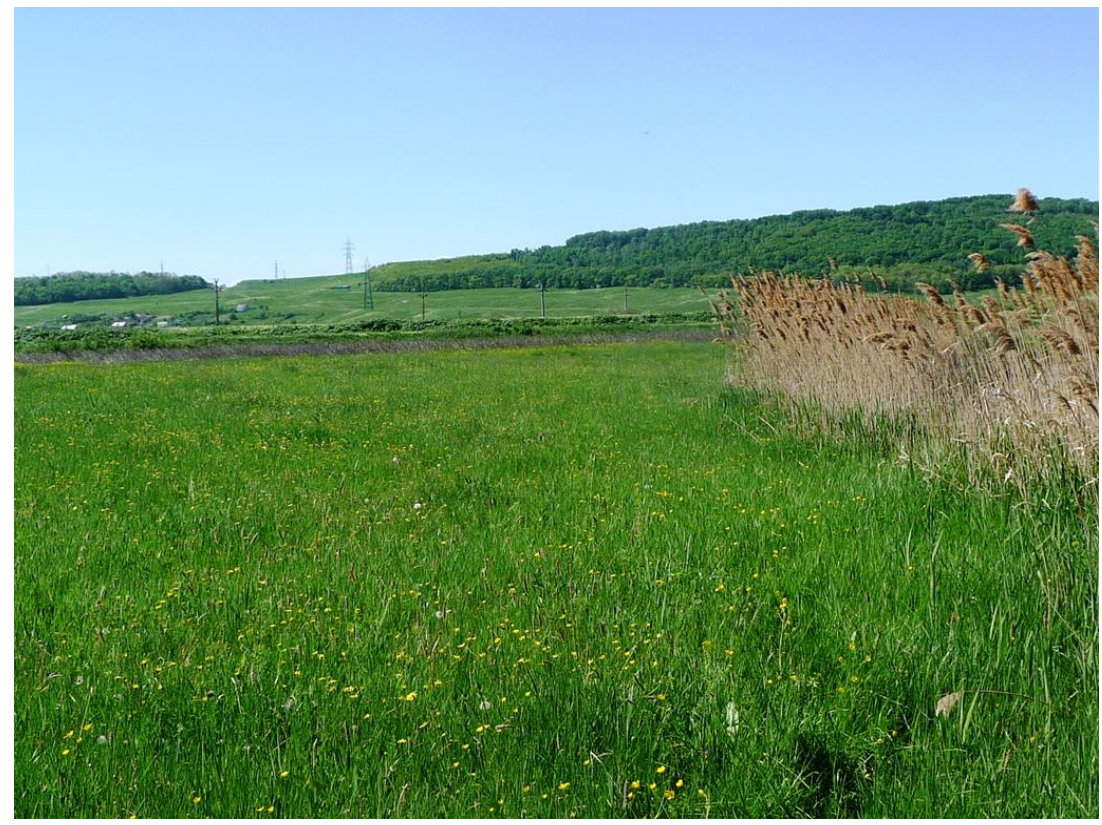

Fig. 7. Meadow with $F$. meleagroides (NE Romania) 
Sozological importance. The inclusion of Romania on the distribution map of the species $F$. meleagroides at the western boundary of its area is an important fact in phyto-geographical terms, especially since in the European part of its area this species is found in various stages of endangerment, being included in the Red Book of vascular plants both in Ukraine (as vulnerable) (Korotchenko \& Orlov 2009), and in Bulgaria (as critically endangered) (Ivanova 2015), or even in the Republic of Moldova (as vulnerable) (Negru 2002) (see however the comments above on the presence of $F$. meleagroides in this country). Since $F$. meleagroides is an endangered species in large parts of its natural range, we consider that urgent actions are necessary for preservation of its population in Romania (i.e., carrying out research on populations in order to establish their sozological status; establishment, by official authorities, of the area in which it grows in Romania as protected area; declaring in the official legislation as a protected species; imposing the mowing regime on meadows and so on).

\section{Conclusions}

The presence of Fritillaria meleagroides in Romania is documented for the first time in this paper. It grows in wet meadows, \pm salinized, situated in Northeastern Romania, North of the village Cotu Morii, on the alluvial plain of the Jijia river, near the border with the Republic of Moldova.

Fritillaria meleagroides differs from the other two congeneric from the vascular flora of Romania, as follows: i) compared to F. meleagris, wherewith it resembles through the alternate leaves, it is distinguished mainly by the smaller flowers, with darker tepals (blackish-purple), obscurely tessellated; by outer gibbosity of tepals (corresponding with the inner nectariferous fovea) less obvious; by nectaries longer, at ca. $4 \mathrm{~mm}$ above the base of tepals; ii) compared to $F$. montana, which has quite similar flowers, it clearly differs through all leaves alternate; iii) it is distinguished by both species through its tolerance to soil salinity.

Fritillaria meleagroides is an endangered species in large parts of its natural range and urgent actions are necessary for preservation of its population in Romania. For this purpose, further research is needed for a more detailed knowledge on the size of populations of this species in Romania, their structure, distribution, ecology, biology and phytosociology.

\section{References}

Andreev, N. (1993). Materiali i kritichni bilezhki za florata na Bulgariya. Hist. Nat. Bulgarica, 4, 29-38.

Artiushenko, Z.T. (1979). Fritillaria L.. In A. Fedorov (red.), Flora partis Europeae URSS, Vol. 4. (pp. 236-237). Leningrad: Nauka.

Assyov, B. \& Petrova, A. (eds). (2006). Konspect na visshata flora na Bulgariya, 3rd ed. Sofia: Bulgarian Biodiversity Foundation.

Baumgarten, J.C.G. (1816). Enumeratio Stirpium Magno Transsilvaniae Principatui. Vol. 1. Vindobonae.

Beldie, A. (1979). Flora României. Determinator ilustrat al plantelor vasculare, Vol. 2. Bucureşti: Edit. Acad. R. S. România.

Bojnanský, V. \& Fargašová, A. (2007). Atlas of Seeds and Fruits of Central and EastEuropean Flora. The Carpathian Mountains Region. Dordrecht: Springer. 
Brândză, D. (1879-1883). Prodromul florei Române. Bucureşti: Tipogr. Acad. Române.

Buko, T.E. \& Maltseva, A.T. (2012). Fritillaria meleagroides Patrin ex Schult. et Schult. fil. In N.Y. Vashlaeva, S.V. Vysotsky, A.N. Kupriyanov et al. (eds), Krasnaia kniga Kemerovskoi oblasti. Tom I, Redkie i nakhodiashchiesia pod ugrozoi ischeznoveniia vidy rastenii i gribov, $2^{\text {nd }}$ ed. (p. 70). Kemerovo: "Asia print".

Bujorean, G. \& Grigore, S. (1965). Fritillaria meleagris L. şi ocrotirea ei. Ocr. Nat., 9(1), 61-68.

Chen, X. \& Mordak, H.V. (2000). Fritillaria L.. In Z.Y. Wu \& P.H. Raven (eds), Flora of China, Vol. 24. (pp. 127-133). Science Press, Beijing \& Missouri Botanical Garden Press, St. Louis.

Chifu, T., Mânzu, C. \& Zamfirescu, O. (2006). Flora \& vegetația Moldovei (România). II. Vegetația. Iaşi: Edit. Univ. "Alexandru Ioan Cuza" Iaşi.

Ciocârlan, V. (2009). Flora ilustrată a României. Pteridophyta et Spermatophyta. 3rd ed., Bucureşti: Edit. Ceres.

Ciubotaru, A., Postolache, G. \& Teleuță, A. (eds). (2007). Lumea vegetală a Moldovei, Vol. 4. Chişinău: Ştiința.

Crawford, R.M.M. (2008). Plants at the margin. Ecological limits and climate change. Cambridge: Cambridge University Press.

Csergő, A.M. \& Frink, J.P. (2003). Some phytocoenological and population structure features of Fritillaria meleagris L. in the upper Şard Valley (Cluj County, Romania). Contrib. Bot. Cluj, 38(2), 163-172.

Didukh, Y.P. (2011). The ecological scales for the species of Ukrainian flora and their use in synphytoindication. Kyiv: Phytosociocentre.

Dihoru, G. \& Negrean, G. (2009). Cartea roşie a plantelor vasculare din România. București: Edit. Acad. Române.

Fuss, M. (1866). Flora Transsilvaniae excursoria. Cibinii.

Geideman, T.S. (1986). Opredelitel' vysshikh rastenii Moldavskoi SSR. $3^{\text {rd }}$ ed, Kishinev: Shtiintza.

GPD (2015). The Global Plants Database. Retrieved November 21, 2015, from: http://plants.jstor.org/search?filter=name\&so=ps_group_by_genus_species+asc\& Query=Fritillaria+meleagroides.

Golub, V.B. (1994). Class Asteretea tripolium on the territory of the former USSR and Mongolia. Folia Geobot. Phytotax., 29, 15-54.

Golub, V.B. \& Saveljeva, L.F. (1991). Vegetation of the Lower Volga Limans (basins without outflow). Folia Geobot. Phytotax., 26, 403-430.

Grecescu, D. (1898). Conspectul florei României. Bucureşti: Tipogr. Dreptatea.

Heuffel, J. (1858). Enumeratio plantarum in Banatu Temesiensis sponte crescentium et frecventius cultarum. Wien: Verh. Zool.-Bot. Ges.

Hill, L. (2008, 2010). Fritillaria Icones, Accession numbers 520, 827. Retrieved November 05, 2015, from: http://www.fritillariaicones.com/.

Ivanova, D. (2015). Fritillaria meleagroides Schult. \& Schult. f. In D. Peev. et al. (eds), Red Data Book of the Republic of Bulgaria, Vol. 1. (pp. 242). Sofia: BAS \& MoEW.

Kanitz, A. (1879-1881). Plantas Romaniae hucusque cognitas. Claudiopoli, Apud E. Demjén. 
Karakaş Metin, Ö., Türktaş, M., Aslay, M. \& Kaya, E. (2013). Evaluation of the genetic relationship between Fritillaria species from Turkey's flora using fluorescentbased AFLP. Turk. J. Biol., 37, 273-279.

Korotchenko, I.A. \& Orlov, A.A. (2009). Fritillaria meleagroides Patrin ex Schult. et Schult. f. In Y.P. Didukh (ed), Tservona Kniga Ukraini. Roslynnyi svit. $3^{\text {rd }}$ ed. Kyiv: Globalconsalting.

Ledebour, C.F. (1830a). Flora Altaica. Vol. 2. Berolini.

Ledebour, C.F. (1830b). Icones plantarum novarum vel imperfecte cognitam, floram Rossicam, imprimis Altaicum. Cent. II. Rigae, Londini, Parisiis, Bruxellae.

Ledebour, C.F. (1853). Flora Rossica sive Enumeratio Plantarum in totius Imperii Rossici. Vol. 4. Stuttgart.

Lozina-Lozinskaya, A.S. (1935). Fritillaria L. In V.L. Komarov (ed), Flora SSSR. Vol. 4. (pp. 302-320). Leningrad: Izd. Nauka.

Maloş, C., Cristea, A. \& Maloş, A. (1967). Pădurea cu lalele pestrițe (Fritillaria meleagris L.) de la Botorogi. Ocr. Nat., 11(1), 85-89.

Mancuso, E., Bedini, G. \& Peruzzi, L. (2012). Morphology, germination, and storage behaviour in seeds of Tuscan populations of Fritillaria montana (Liliaceae), a rare perennial geophyte in Italy. Turk. J. Bot., 36, 161-166.

Negru, A. (ed). (2002). Cartea roşie a Republicii Moldova, $2^{\text {nd }}$ ed. Chişinău: Ştiința.

Negru, A. (2007). Determinator de plante din flora Republicii Moldova. Chişinău: Edit. "Universul".

Oltean, M., Negrean, G., Popescu, A., Roman, N., Dihoru, G., Sanda, V. \& Mihăilescu, S. (1994). Lista Roşie a plantelor superioare din România. In M. Oltean (coord.). Studii, sinteze, documentați de ecologie, Academia Română, Institutul de Biologie, 1, 1-52.

Oprea, A. (2005). Lista critică a plantelor vasculare din România. Iaşi: Edit. Univ. "Alexandru Ioan Cuza".

Pachoskiy, Y.K. (1914). Khersonska flora. Kherson.

Peruzzi, L. \& Bartolucci, F. (2009). Typification of the names within Fritillaria montana complex (Liliaceae) from central Mediterranean area. Candollea, 64, 133-142.

Peruzzi, L., Mancuso, E., Ansaldi, M., De Angeli, E. \& Trombetti, G. (2008). Distribuzione, caratterizzazione e consistenza delle popolazioni toscane di Fritillaria montana Hoppe (Liliaceae). Webbia, 63(2), 309-315.

Petrova, A. \& Vladimirov, V. (eds). (2009). Red list of Bulgarian vascular plants. Phytologia Balcanica, 15(1), 63-94.

Pînzariu, P. \& Sîrbu, T. (2014). Flora vasculară din Republica Moldova (Lista speciilor şi ecologia). Chişinău: Tipogr. "Garamont-Studio".

Pop, E. \& Sălăgeanu, N. (1965). Monumente ale naturii din România. Bucureşti: Edit. Meridiane.

Prodan, I. (1939). Flora pentru determinarea şi descrierea plantelor ce cresc $\hat{\imath}$ România, $2^{\text {nd }}$ ed., Vol. 1. Cluj: Tipogr. Cartea Românească.

Prokudin, I.N., Dobrochaeva, D.N., Zaverukha, B.V., Chopik, V.I., Protopopova, V.V. \& Critskaia, L.I. (eds). (1987). Opredelitel' vyshikh rastenii Ukrainy. Kiev: Naukova Dumka. 
Rix, E.M. (1980). Fritillaria L.. In T.G. Tutin, N.A. Burges, A.O. Chater, J.R. Edmondson, V.H. Heywood, D.M. Moore, D.H. Valentine, S.M. Walters \& D.A. Webb (eds), Flora Europaea. Vol. 5 (pp. 31-34). Cambridge: Cambridge University Press.

Rønsted, N., Law, S., Thornton, H., Fay, M.F. \& Chase, M.W. (2005). Molecular phylogenetic evidence for the monophyly of Fritillaria and Lilium (Liliaceae; Liliales) and the infrageneric classification of Fritillaria. Molec. Phylogen. Evol., 35, 509-527.

Sămărghițan, M. \& Oroian, S. (2011). Meadows with Fritillaria meleagris L. at Lunca Mureşului - Aluniş, Mureş county. Argesis, Stud. Comun., Ser. Şti. Nat., 19, 3147.

Sârbu, I. \& Chifu, T. (2001). Lista roşie a plantelor vasculare din Moldova. Memoriile Sect. Şti. Acad. Română, Ser. 4, 24, 131-151.

Sârbu, I., Negrean, G., Oprea, A. \& Cristurean, I. (2003). Lista speciilor amenințate la nivel European (Aii) şi care se regăsesc şi în România (incluse în Directiva Habitate - Anexa IIb şi IVb, Convenția de la Berna-Appl). In A. Sârbu (ed), Ghid pentru identificarea importantelor arii de protecție şi conservare a plantelor din România (pp. 45-58). Bucureşti: Edit. Alo, Bucureşti!.

Sârbu, I., Ştefan, N. \& Oprea, A. (2013). Plante vasculare din România. Determinator ilustrat de teren. Bucureşti: Edit. Victor B Victor.

Schultes, J.A. \& Schultes, J.H. fil. (1829). Fritillaria. In J.J. Roemer \& J.A. Schultes (eds.), Systema vegetabilium, ed. 15 bis, (pp. 385-399). Stuttgart.

Schur, J.F. (1866). Enumeratio Plantarum Transsilvaniae. Vindobonae.

Simonkai, L. (1886). Erdély edényes flórájának helyesbitett foglalata (Enumeratio florae Transsilvaniae vesculosae critica). Budapest: Kiadja A Kir. Magyar Természettudományi Társulat.

Stpiczyńska, M., Nepi, M. \& Zych, M. (2012). Secretion and composition of nectar and the structure of perigonal nectaries in Fritillaria meleagris L. (Liliaceae). Plant Syst. Evol., 298, 997-1013.

Tomović, G., Vukojičić, S., Niketić, M., Zlatković, B. \& Stevanović, V. (2007). Fritillaria (Liliaceae) in Serbia: distribution, habitats and some taxonomic notes. Phytologia Balcanica, 13(3), 359-370.

Türktaş, M., Aslay, M., Kaya, E. \& Ertuğrul, F. (2012). Molecular characterization of phylogenetic relationships in Fritillaria species inferred from chloroplast trnLtrnF sequences. Turk. J. Biol., 36, 552-560.

Vlasova, N.V. (1987). Fritillaria L. In L.I. Malysheva \& G.A. Peshkova (eds.), Flora Sibiri. Vol. 4, Araceae - Orchidaceae. (pp. 99-101). Novosibirsk: Nauka, Sibirskoe otdelenie.

Ularu, P. \& Parascan, D. (1970). Câteva date fitocenologice asupra lalelei pestrițe (Fritillaria meleagris L.) în depresiunea Braşovului şi împrejurimi. Ocr. Nat., 14(1), 69-72.

Yanev, A. (1964). Fritillaria L. In D. Jordanov (ed), Flora na Narodna Republika Bulgariya (Flora Reipublicae Popularis Bulgaricae). Vol. 2 (pp. 254-265). Aedibus Acad. Sci. Bulgaricae, Serdicae.

Zahariadi, C. (1966). Fritillaria L. In T. Săvulescu (ed), Flora R. S. Romania. Vol. 9. (pp. 287-295). Bucureşti: Edit. Acad. R. S. România. 
Table 1 Morphometric data on F. meleagroides. Data from Romania is based on measurements taken from 10 specimens (med.-medium size, min.-max. - minimum-maximum size, CV\% - coefficient of variation)

\begin{tabular}{|c|c|c|c|c|c|c|c|c|c|}
\hline \multirow[b]{2}{*}{ Characters } & \multicolumn{3}{|c|}{ Romania } & \multicolumn{6}{|c|}{ Data from references } \\
\hline & med. & $\min .-\max$. & $\mathrm{CV} \%$ & $\begin{array}{c}\text { Schultes \& } \\
\text { Schultes } \\
1829 \\
\end{array}$ & $\begin{array}{c}\text { Lozina- } \\
\text { Lozinskaya } \\
1935\end{array}$ & $\begin{array}{c}\text { Yanev } \\
1964 \\
\end{array}$ & $\begin{array}{c}\text { Rix } \\
1980 \\
\end{array}$ & $\begin{array}{c}\text { Chen \& } \\
\text { Mordak } \\
2000\end{array}$ & $\begin{array}{c}\text { Bojnanský \& } \\
\text { Fargašová } \\
2007\end{array}$ \\
\hline $\mathbf{0}$ & 1 & 2 & 3 & 4 & 5 & 6 & 7 & 8 & 9 \\
\hline Plant height $(\mathrm{cm})$ & 37.6 & $28-50$ & 20.1 & & $25-60$ & $25-60$ & $25-60$ & $20-40$ & $25-60$ \\
\hline Length of internodes $(\mathrm{cm})$ & 5.8 & $4.7-7.1$ & 15.2 & & & & & & \\
\hline No. of leaves & 5.9 & $5-7$ & 14.8 & ca. 4 & $3-7$ & $3-7(-9)$ & $3-6(-7)$ & $3-7$ & \\
\hline Lowermost leaf length (cm) & 12.0 & $11-14$ & 7.9 & 14 & $5-15$ & $4-15$ & $7-16$ & $5-15$ & \\
\hline Lowermost leaf width (mm) & 6.2 & $5-8$ & 15.4 & ca.5 & up to 7 & up to 7 & up to 7 & up to 5 & \\
\hline Number of flowers & 1 & - & - & 1 & 1 & $1(2-3)$ & 1 & usually 1 & 1 \\
\hline Peduncle / bracteant leaf ratio & 0.9 & $0.5-2.1$ & 56.6 & & $>1$ & $<1$ & ca. 1 & variable & \\
\hline Tepal length (mm) & 26.4 & $25-28$ & 5.1 & 29 & $20-30$ & $20-30$ & $20-25$ & $20-30$ & \\
\hline Outer tepals width (mm) & 10.1 & $8-11$ & 8.4 & $8.4-9.5$ & & $6-7(-9)$ & $7-9$ & $5-8$ & \\
\hline Inner tepals width $(\mathrm{mm})$ & 15.1 & $12-18$ & 13.7 & (indistinct) & up to 12 & $7-12$ & 10 & $7-12$ & \\
\hline Position of nectaries ( $\mathrm{mm}$, from the base of tepal) & 4.3 & $4-5$ & 10.0 & & & & 4 & & \\
\hline Nectaries length $(\mathrm{mm})$ & 14.3 & $12-18$ & 11.4 & & & & 15 & 15 & \\
\hline Nectaries width (mm) & 1.5 & $1-1.5$ & 10.9 & & & & 2 & 2 & \\
\hline Stigma branches length $(\mathrm{mm})$ & 3.2 & $3-4$ & 10.9 & & & & $3-4$ & & \\
\hline Style length (mm) & 6.2 & $5-7$ & 14.8 & & & & 7 & $4-8$ & \\
\hline Stamens / tepals ratio & 0.57 & $0.5-0.6$ & 9.9 & ca. 0.5 & 0.5 & 0.5 & & 0.66 & \\
\hline Capsule length (mm) & 22.5 & $15-35$ & 19.4 & & 20 & 20 & & & \\
\hline Capsule width (mm) & 10.3 & $8-12$ & 19.0 & & 10 & 10 & & & \\
\hline Length of narrowed region at the bottom of capsule (mm) & 2.3 & $1-4$ & 36.7 & & & & & & \\
\hline Seed length $(\mathrm{mm})$ & 5.0 & $4-6$ & 13.1 & & & & & & $6-6.6$ \\
\hline Seed width (mm) & 3.6 & $3-4$ & 11.6 & & & & & & $4.8-5.2$ \\
\hline
\end{tabular}

